Article

\title{
Development of an Integrated Water Quality and Macroalgae Simulation Model for Tidal Marsh Eutrophication Control Decision Support
}

\author{
Yan Chen ${ }^{1,2}$, Rui Zou ${ }^{3, *}$, Han $\mathrm{Su}^{1}{ }^{1}$, Sen Bai ${ }^{3}$, Mustafa Faizullabhoy ${ }^{3}$, Yueying Wu ${ }^{2}$ \\ and Huaicheng Guo ${ }^{1, *}$ \\ 1 College of Environmental Sciences, Peking University, Beijing 100871, China; ychenychen@163.com (Y.C.); \\ tygt12@163.com (H.S.) \\ 2 Department of Water Environmental Planning, Chinese Academy for Environmental Planning, \\ Beijing 100012, China; wuyy@caep.org.cn \\ 3 Tetra Tech, Inc., 10306 Eaton Place, Ste. 340, Fairfax, VA 22030, USA; Sen.Bai@Tetratech.com (S.B.); \\ mustafa.faizullabhoy@tetratech.com (M.F.) \\ * Correspondence: rz5q2008@gmail.com (R.Z.); hcguo@pku.edu.cn (H.G.)
}

Academic Editor: Benoit Demars

Received: 1 March 2017; Accepted: 12 April 2017; Published: 15 April 2017

\begin{abstract}
Numerical modeling is an efficient and useful method for understanding the hydrodynamics and water quality responses to nutrient loading changes and other management in estuarine and coastal systems. In this study, the Environmental Fluid Dynamic Code (EFDC) was applied in the Famosa Slough, a small tidal marsh system in urban San Diego County, California, to analyze multiple management scenarios focusing on different aspects of controlling processes: watershed load reduction, macroalgae harvesting, dredging, and the combination of different options. In order to evaluate these management scenarios, a previous EFDC model was enhanced through modifying the model code to allow simulations of both benthic and floating macroalgae as separate state variables, and configuring a sediment diagenesis model to predictively represent the dynamic interactions between the watershed load and benthic nutrient flux. The model was calibrated and verified by comparing model predictions with the observed data of hydrodynamic and water quality parameters throughout 2008. The calibrated model was then applied to simulate the water quality response to various management scenarios. The simulated results showed that combining watershed nutrient load reductions and harvesting floating macroalgae can produce significant water quality benefits. The results provide useful information for hydrological ecosystem protection and can be used for determining cost-effective implementation actions in the future.
\end{abstract}

Keywords: numerical modeling; water quality; eutrophication; floating macroalgae; sediment diagenesis

\section{Introduction}

Water quality deterioration caused by human waste disposal and agricultural non-point source pollution has become a widespread environmental issue in recent years [1-3]. Eutrophication has become a serious problem for most of the freshwater and coastal marine ecosystems around the world. Severe eutrophication problems involving blooms of cyanobacteria and fish kills can result in losses of ecological integrity, sustainability, and safe use of aquatic ecosystems [4-8]. Eutrophication restoration approaches, such as watershed loading reduction, floating macroalgae harvest, and sediment dredging, are effective remedies for alleviating eutrophication problems in many surface water bodies [6,9-11]. Identification of the optimal implementation levels for the multiple 
eutrophication restoration approaches is desired to achieve multiple targets, including minimization of economic cost and maximization of eutrophication restoration degree [12-16]. However, such a process may be fraught with complexities due to the spatial diversities of hydrological cycles, physical and biochemical processes of water contaminants, as well as the nonlinear response of water quality to the combination of engineering approaches. Therefore, it is necessary to develop an eutrophication modeling system to assess the effects of eutrophication restoration approaches on water quality. Environmental fluid dynamics code (EFDC) is a general purpose modeling package for simulating one-, two-, and three-dimensional flow, transport, and bio-geochemical processes in surface water systems [17-21]. EFDC is an alternate and more versatile surface water modeling system, which includes hydrodynamics, sediment transport, toxic contaminant transport, and water quality-eutrophication components [22-24]. The structure of the EFDC model includes four major modules: (i) a hydrodynamic sub-model; (ii) a water quality sub-model, (iii) a sediment transport sub-model; and (iv) a toxic sub-model $[25,26]$. The water quality portion of the model simulates the spatial and temporal distributions of 22 water quality parameters including dissolved oxygen, suspended algae (three groups), attached algae, various components of carbon, nitrogen, phosphorus, and silica cycles, and bacteria.

The EFDC model was originally developed at the Virginia Institute of Marine Science for estuarine and coastal applications. This model is now being supported by USEPA (United States Environmental Protcction Agency) and has been used extensively to support total maximum daily load (TMDL) development throughout the country [23,27]. Over the last two decades, EFDC has been used extensively to simulate hydrodynamic and water quality processes in rivers, lakes, estuaries, reservoirs, wetlands, and coastal regions [19,22,28-30]. EFDC is also capable of simulating cohesive and non-cohesive sediment transport, near field and far field discharge dilution from multiple sources, eutrophication processes, transport and fate of toxic contaminants in the water and sediment phases, and transport and fate of various life stages of finfish and shellfish [24,31-36].

This study uses EFDC as the computational framework to develop a decision support tool for the Famosa Slough water quality restoration effort. The Famosa Slough is a 22 -acre lagoon, and a 10-acre channel connects the lagoon with the tidal portion of the San Diego River draining into the San Diego Bay. The slough is flushed with salt water from the San Diego Bay, and also receives freshwater from the surrounding watershed. The 12-acre channel portion and the 22-acre southern portion of the slough are owned and maintained by the City of San Diego. Both portions are accessible by the public, and beaches are located at view areas. The Famosa Slough system serves as an important habitat and recreational water resource for the city of San Diego. It has long suffered water quality impairment due to low dissolved oxygen and high coverage of floating macroalgae. Therefore, water quality restoration is very important for this system.

While water quality models such as EFDC have long been widely applied in supporting water quality restoration decision making, such modeling analyses generally are focused on external load reduction analysis $[21,28,30,37,38]$. To our knowledge, no reported research has addressed the development of integrated, spatially explicit hydrodynamic and water quality models that are capable of assessing the water quality response (macroalgae, dissolved oxygen, nutrients) to multiple aspect water quality restoration options including external load reduction, sediment dredging, and macroalgae harvesting in a holistic framework. However, such a modeling framework is of particular importance for the decision support of the Famosa Slough restoration because these multiple aspect options have long been envisioned as potential alternatives that are viable for improving the water quality condition in the Slough [34-36].

The development of the EFDC model for Famosa Slough restoration analysis has experienced a long process through which the model was continuously evolving in terms of representation robustness and versatility. The first version of the model was originally developed in 2011, and then it has been improved several times based on the TMDL (Total Maximum Daily Loads) modeling needs and the increased understanding of hydrodynamics and water quality processes likely to control 
water quality within the Slough, Channel, and the estuarine portion of the San Diego River. Until 2013, two refinements had been made to improve the EFDC model of the Famosa Slough by extending the tidal boundary conditions from the channel outlet to the mouth of the San Diego River, and by applying spatially variable kinetics for algae and macrophyte based on local research.

While the model was improved through the previous refinements, it was still subjected to several constraints that limit its predictive capability for reasonably evaluating practical management scenarios such as harvesting of floating macroalgae, dredging, and even watershed load reduction. One limitation of the model was that it represented the floating macroalgae and benthic algae as a lumped state variable; however, in reality the two groups of macroalgae significantly differ from each other in their responses to light, temperature, and water depth. Lumping them together would lead to an unreasonable prediction of the macroalgae dynamics, and would not allow the model to represent the competitive interactions between the two macroalgae groups and therefore the consequence of the harvesting of floating macroalgae. The other limitation is that the model represents the benthic nutrient flux and sediment oxygen demand (SOD) as the specified flux, therefore, the model was not able to represent the response of benthic flux to management scenarios. Since benthic flux is a significant nutrient source to the water column in the Famosa Slough system, it is critical to have the capability of predicting the benthic nutrient fluxes in response to management scenarios.

In order to more reliably determine management options, in this study, the hydrodynamic and water quality sub-models, together with a sediment diagenesis model, were updated and applied to simulate the Famosa Slough for TMDL development. The background of the study area and the general refined model information will be introduced and will be followed by calibration and verification. Then management scenarios and their effects are then evaluated. Recommendations are given in the last section.

\section{Methodology}

\subsection{Study Area}

The Famosa Slough watershed is a small, 358-acre, coastal watershed in San Diego County. It is located entirely within the City of San Diego and is between Ocean Beach and Loma Portal. The watershed encompasses the 22-acre Famosa Slough lagoon and a 10-acre channel which connects the lagoon with the tidal portion of the San Diego River via tide gates.

In order to address the water quality problem of the tidal marsh system, decision makers need to identify with the help of science what among the previously proposed management options would be effective in restoring the water quality in the Slough. The previously proposed management options are based on different aspects of controlling processes: watershed load reduction, macroalgae harvesting, and the combination of different options. This study focuses on the area of the Slough, Channel, and the estuarine portion of the San Diego River.

\subsection{Model Modification}

In light of the key limitations of the model, an iteration of model improvement was necessary to improve the predictive capability for reasonably evaluating potential management scenarios. Two key model improvements included: (1) improvement in the model predictive capability through separating the floating macroalgae and benthic macroalgae groups; (2) improvement in the model predictive capability through configuring a sediment diagenesis model to directly simulate the interaction between watershed loading, ocean boundary loading, San Diego River loading, and benthic nutrient flux and SOD. The following summarizes the key model enhancement/corrections that were included in the refinement.

\subsubsection{EFDC Code Modification to Simulate Floating Macroalgae}

A code modification was conducted to allow the EFDC model to simulate floating macroalgae using the first algae group. The first algae group in the standard EFDC model simulates phytoplankton, 
and the modified code allowed the use of the first algae group as a state variable for macroalgae when the corresponding transport flag was set to a value of two. A value of two deactivates the advective and dispersive/diffusive transport for phytoplankton. Also, the light limitation factor was removed for floating macroalgae based on the assumption that the floating macroalgae would occupy the surface of the water and is always at the most desired light condition. The shading effect of floating macroalgae on the benthic macroalgae was represented by a light extinction factor which was linearly related to the biomass of the floating macroalgae. Hence, the kinetic equation for the floating macroalgae is the same as that of the first algae group in the EFDC theoretical manual except for the turning off of advection/diffusion as well as light limitation. Interested readers might refer to [38,39] for details of the model equations.

\subsubsection{Sediment Diagenesis Model Development}

A sediment diagenesis model was developed based on the EFDC benthix flux module to represent the interactions between the external nutrient loading, floating and benthic macroalgae, phytoplankton, and benthic nutrient flux and SOD dynamics. This addition allows the model to predict the water quality response to management scenarios in a more reliable and realistic way. For example, harvesting floating macroalgae results in a reduction in organic matter deposition to the sediment, which causes a reduction in benthic nutrient flux and SOD. Without the predictive sediment diagenesis model, the model was not able to evaluate the response of water quality and benthic flux to such management scenarios.

\subsection{Model Configuration}

Model development requires defining the computational domain and boundary conditions. The general steps to set up the EFDC model for the Famosa Slough included generating the modeling grid, defining meteorological conditions, estimating oceanic inputs, and linking the watershed (LSPC) model to EFDC. Key data sources were compiled to support development of the Slough model. Model development steps and data used to identify initial conditions, boundary assignments, and calibration of key model parameters are discussed below.

\subsubsection{Grid Generation}

The Famosa Slough receiving water model is composed of three portions: the Famosa Slough, Famosa Channel, and the tidal reach of the San Diego River. The Slough and Channel are connected by hydraulic structures (culverts) that govern the direction of flow either into or out of the Slough. Figure 1 illustrates the general layout of the Famosa Slough, Famosa Channel, and the San Diego River. Model grid generation was based on a bathymetric survey of the Famosa Slough that was performed in March 2008. These data include bottom elevations that were measured at several locations throughout the Slough and Channel. The depth-averaged model domain was discretized into a grid consisting of 545 quadrilateral computational cells. The tidal reach of the San Diego River, located between the ocean inlet at Dog Beach and the I-5 bridge, was discretized into 28 rectangular computational cells.

\subsubsection{Boundary Conditions}

In order to simulate water circulation and eutrophication dynamics using the EFDC model, proper boundary conditions must be specified. Boundary conditions include watershed freshwater inflows and associated nutrient loadings directly to the Famosa Slough, Famosa Channel, and the San Diego River. Hydrodynamics and water quality transport within the San Diego River are also controlled by tidal boundary conditions, which include specification of tidal water level variations and water quality parameter concentrations over time, at its interface with the Pacific Ocean.

Flow rates and nutrient loading from different sub-watersheds were assigned as boundary conditions to the EFDC model. The EFDC grid cells that receive flow and nutrient loading from different sub-watersheds were determined based on the natural drainage of the sub-basin. Salt loadings 
from the direct drainage areas were set to zero, and salt loadings from the ocean were specified based on a constant ocean salinity of 35 parts per thousand (PPT). The LSPC model simulated flow rates, total nitrogen, and total phosphorous loading rates. Partitioning of the LSPC predicted TP and TN loads into $\mathrm{NH}_{4}{ }^{+}-\mathrm{N}, \mathrm{NO}_{3}{ }^{-}-\mathrm{N}$, organic $\mathrm{N}$ forms, $\mathrm{PO}_{4}{ }^{-} \mathrm{P}$, and organic $\mathrm{P}$ forms based on a previous study.

The impact of the ocean water hydrodynamics was represented in EFDC through specification of tidal boundary conditions based on measured (6-minute interval) water surface elevations at Scripps Pier (La Jolla), measured (15-minte interval) water temperature variations at the outlet of the Famosa Channel, and specification of constant values of salinity and other water quality constituents that are typical of coastal waters (Table 1).
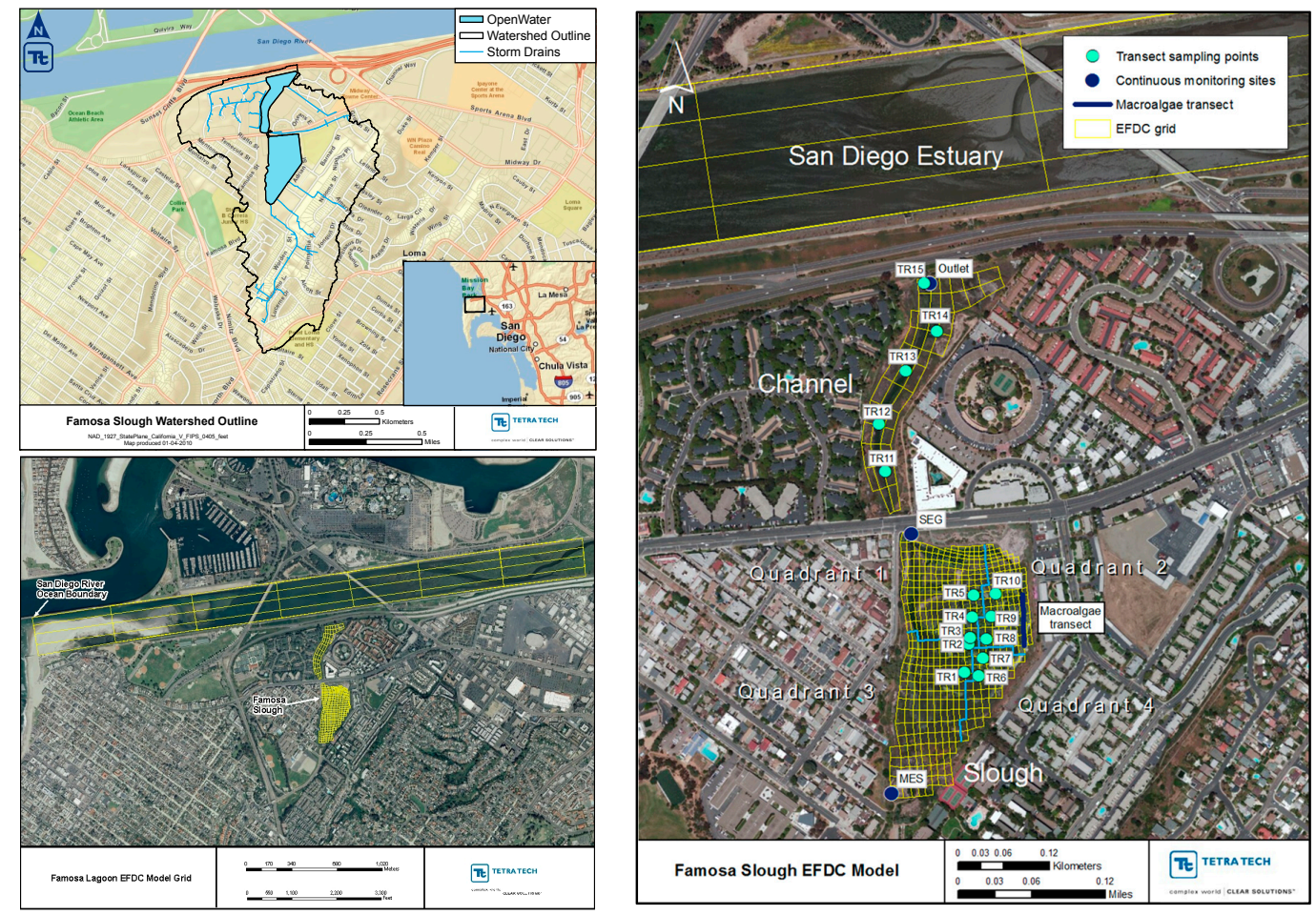

Figure 1. Environmental Fluid Dynamic Code (EFDC) Grid, sampling point, and watershed outline for the Famosa Slough, Famosa Channel, and the San Diego River.

Table 1. Nutrient Ocean Boundary Conditions.

\begin{tabular}{cc}
\hline Variable & Concentration \\
\hline Ammonia-Nitrogen $\left(\mathrm{NH}_{4}{ }^{+}-\mathrm{N}\right)$ & $0.04 \mathrm{mg} / \mathrm{L}$ \\
Nitrate-Nitrogen $\left(\mathrm{NO}_{3}{ }^{-}-\mathrm{N}\right)$ & $0.02 \mathrm{mg} / \mathrm{L}$ \\
Organic Nitrogen $(\mathrm{ON})$ & $0.01 \mathrm{mg} / \mathrm{L}$ \\
Phosphate $\left(\mathrm{PO}_{4}{ }^{-}-\mathrm{P}\right)$ & $0.01 \mathrm{mg} / \mathrm{L}$ \\
Organic Phosphorous $(\mathrm{OP})$ & $0.01 \mathrm{mg} / \mathrm{L}$ \\
\hline
\end{tabular}

A sediment diagenesis model was developed to dynamically link the benthic nutrient flux and SOD to watershed loading, San Diego River loading, ocean boundary loading, fate and transport of nutrients, floating and benthic macroalgae, and phytoplankton dynamics in the system.

Data required for model setup include atmospheric pressure, air temperature, relative humidity, precipitation, cloud cover, solar radiation, wind speed, and wind direction. Hourly measurements were obtained from the NOAA (National Oceanic and Atmospheric Administration) National Climate Data Center for the San Diego Airport which is located approximately 3 kilometers southeast of the Famosa Slough. 


\subsubsection{Initial Conditions}

In hydrodynamic and water quality modeling, initial conditions provide a starting point for the model to march forward through time. In this study, an iterative approach was adopted to derive the initial sediment condition, which uses the end of year simulated bed condition as the initial condition for the next calibration iteration. Using this approach, the initial condition for sediment diagenesis will gradually converge to a condition that reflects the complex interaction in the calibrated model.

\section{Model Calibration and Verification}

The model calibration process for the Famosa Slough used data that were collected by the Southern California Coastal Water Research Project (2010) and the City of San Diego (2009). The majority of data collected during the monitoring effort were continuous monitoring data at three monitoring stations. Because of the large amount of data available, these monitoring stations were used for hydrodynamic and water quality model calibration. In addition to continuous monitoring at these three sites, Index Period monitoring was conducted during four events throughout 2008 representing each of the four periods. Each event included grab sample collection for seven days over a period of two consecutive weeks at the three continuous monitoring stations and transects within the Channel and Slough.

\subsection{Hydrodynamic Calibration}

During calibration of the hydrodynamic model, predicted water surface elevations (WSE), water temperatures, and salinities were compared to continuous sonde measurements of water depth, water temperature, and conductivity, at the above three monitoring stations. Water temperature and conductivity data were also collected independently of the continuous sonde measurements using a hand-held multi-parameter monitoring instrument YSI meter (YSI incorporated ${ }^{\circledR}$, Yellow Spring, $\mathrm{OH}, \mathrm{USA}$ ) during the four Index Monitoring Periods.

Figure 2a show comparisons of simulated and measured water surface elevations (WSE) at the outlet monitoring locations, respectively, for the entire simulation period (1 January-31 December, 2008). Generally, there is good agreement between measured and predicted tidal water level variations at all three monitoring locations. Figure $2 \mathrm{~b}$ shows comparisons of simulated and measured salinity at the outlet for the entire simulation period (1 January-31 December 31, 2008). Figure 2c shows comparisons of simulated and measured water temperature at the outlet for the entire simulation period (1 January-7 October, 2008). In summary, the EFDC hydrodynamic calibration results shown in Figure 2 suggest that the model adequately simulates the propagation of both freshwater and seawater inputs into and out of the Slough, Channel, and San Diego River. They also suggest the validity of the culvert rating curves used to control the exchange of water between the Slough, the Channel, and the San Diego River estuary.

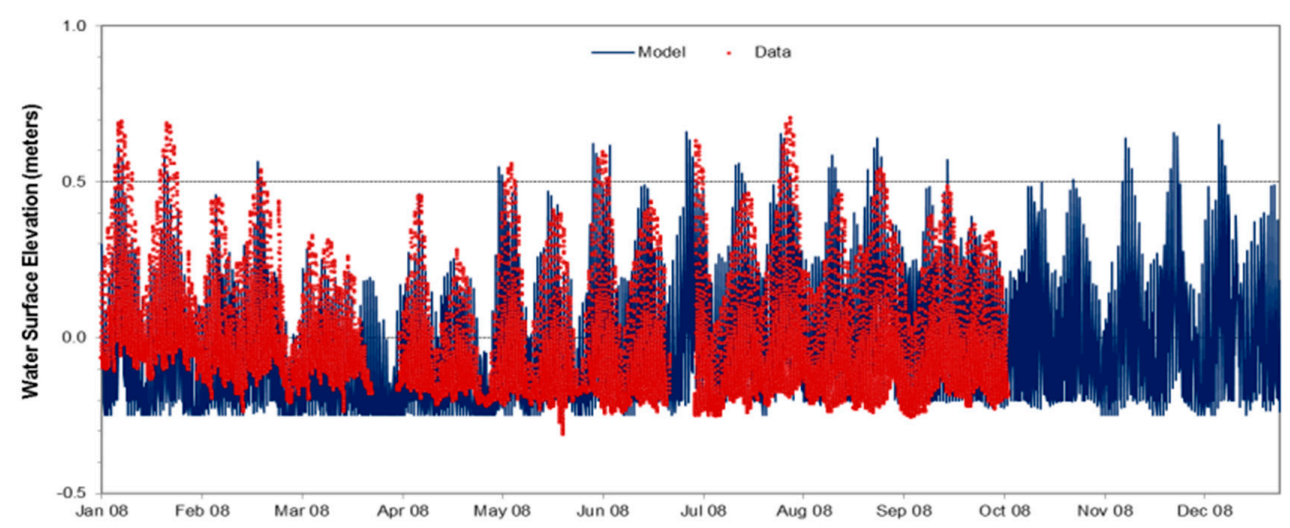

(a)

Figure 2. Cont. 


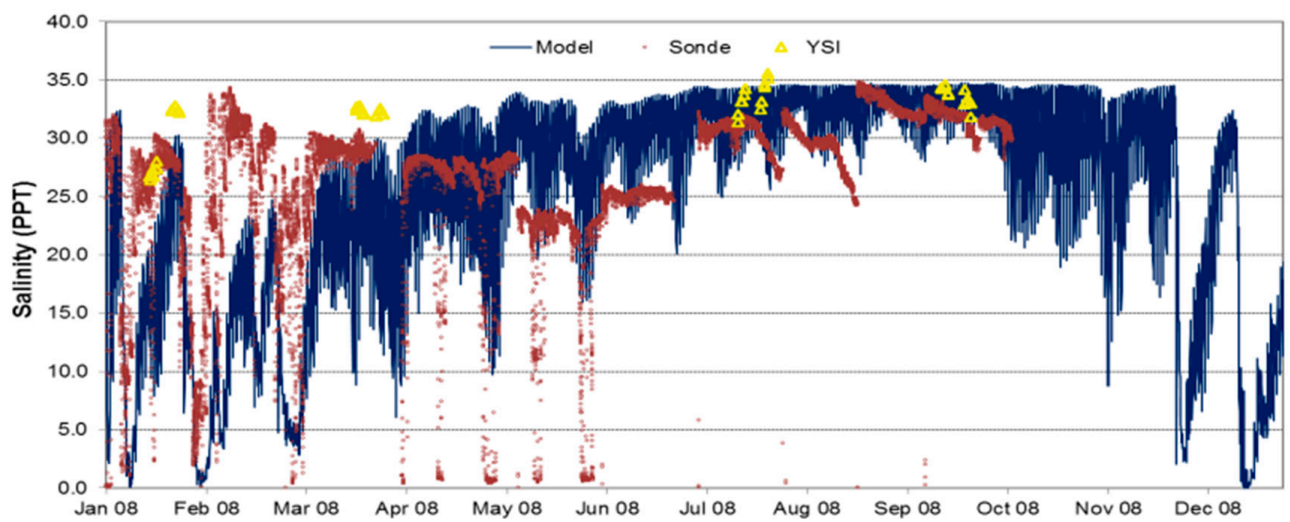

(b)

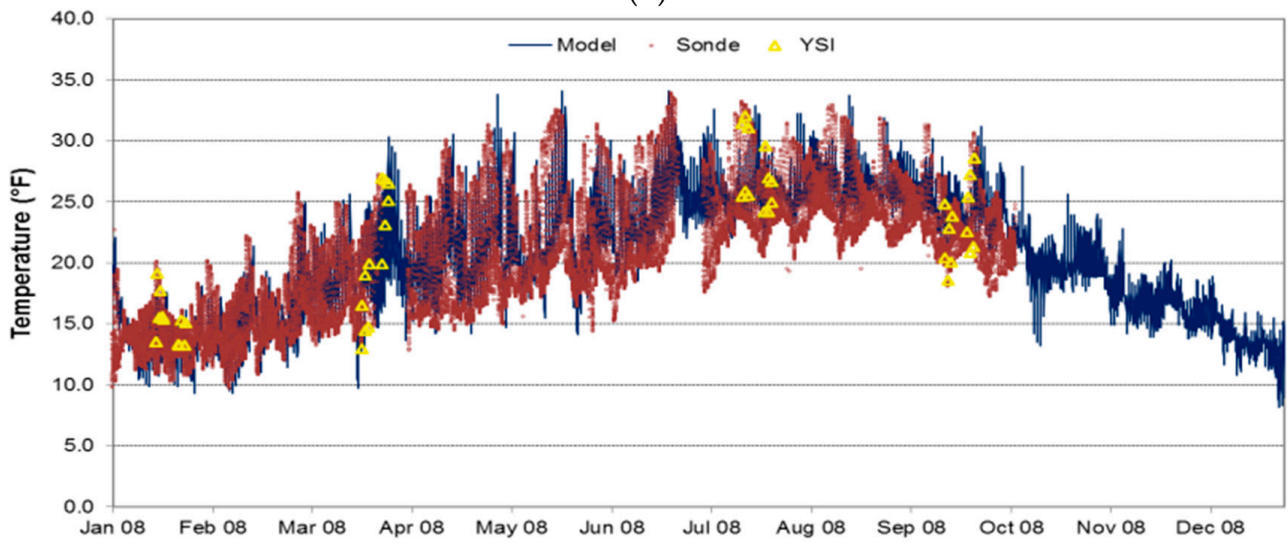

(c)

Figure 2. The following subset of the state variables available within the EFDC Comparison of observed and simulated water level variations for water surface elevations (a), salinity (b), and water temperature (c) at the Famosa Channel outlet.

\subsection{Water Quality Model Calibration}

water quality module were selected to simulate the eutrophication dynamics within the Famosa Slough, Famosa Channel, and the San Diego River: phytoplankton algae, floating macroalgae, benthic macroalgae, refractory and labile particulate organic carbon, dissolved organic carbon, refractory and labile particulate organic phosphorus, dissolved organic phosphorus, total phosphorus, refractory and labile particulate organic nitrogen, dissolved organic nitrogen, ammonia nitrogen, nitrate plus nitrite nitrogen, and dissolved oxygen.

The calibration process for water quality involves varying parameters and kinetics values within reasonable and observed ranges to reproduce the observed spatial and time varying water quality distributions within the Slough, Channel, and San Diego River estuary. The model spatial domain was divided into four zones for the purpose of specifying varying algal growth, settling, benthic sediment fluxes, and eutrophication kinetics, as needed. The three key zones are the Slough, Channel, and San Diego River estuary. The fourth zone includes a small area immediately surrounding the MES (Famosa Slough Southern End Monitoring Station) station. Table 2 presents a summary of the eutrophication kinetics used in the water quality calibration. As can be seen, the phytoplankton and benthic macroalgae respectively have a maximum growth rate of 1.1 and $0.5 /$ day, which are within the range presented in the literature for macrophyte and periphyton [36].

The maximum growth rate of 1.2 to 1.5/day for the floating macroalgae, on the other hand, does appear to be excessive. In the several years of modeling Famosa, a tremendous amount of effort has been devoted to exploring parameterization that allows reproduction of the extremely large diurnal DO (Dissolved Oxygen) range, namely from near 0.0 to $>20.0 \mathrm{mg} / \mathrm{L}$, and all of these efforts all lead to 
the same conclusion: it is possible to produce the extremely high diurnal DO fluctuation if and only if the floating macroalgae has the growth rate as high as that presented in Table 2. This suggests that the macroalgae that dominate the Famosa Slough would likely possess such high growth properties. We are anticipating that future researchers of macroalgae ecology might study the floating macroalages in the Famosa Slough to provide further data for refining the insights we obtained from the model.

Table 2. Summary of Kinetic Parameters used in Water Quality Modeling.

\begin{tabular}{cc}
\hline Parameter & Value \\
\hline Algal maximum growth rate & $1.1 /$ day \\
Benthic macroalgae maximum growth rate & $0.5 /$ day \\
Floating macroalgae maximum growth rate & 1.2 to $1.5 /$ day \\
Phosphorus half-saturation conc., algae & $0.001 \mathrm{mg} / \mathrm{L}$ \\
Phosphorus half-saturation conc.,macroalgae & $0.001 \mathrm{mg} / \mathrm{L}$ \\
Nitrogen half-saturation conc., algae & $0.01 \mathrm{mg} / \mathrm{L}$ \\
Nitrogen half-saturation conc., benthic macroalgae & $0.01 \mathrm{mg} / \mathrm{L}$ \\
Settling velocity of algae & $0.2 \mathrm{~m} / \mathrm{day}$ \\
Settling velocity of particulate organic matter & $0.5 \mathrm{~m} / \mathrm{day}$ \\
Carbon-to chlorophyll ratio of algae & $0.06 \mathrm{mgC} / \mathrm{ug} \mathrm{Chl}$ \\
O'Conner-Dobbins Reaeration Rate Constant & 3.933 \\
\hline
\end{tabular}

In addition, the modeling study also finds that the half saturation rate for macroalgaes must be set to low values, such as 0.001 for $\mathrm{P}$, and 0.01 for $\mathrm{N}$ in order to allow prediction of the observed extreme DO diurnal signal. This suggests that the macroalgae in Famosa is likely to be very efficient in uptaking nutrients from the water quality to maintain the high productivities, which is indirectly proven by the large DO diurnal fluctuation. Although slightly higher values might be used that still achieve similar model performance, the lower value was adopted considering that the purpose of this modeling study was to support the TMDL development, therefore, to set the half saturation concentration to the lower value would contribute to the conservativeness of the scenario analysis result, which would avoid potential over-prediction of the response of macroalgae to nutrient reduction.

\subsubsection{Simulation Results of Chlorophyll-a}

Figure 3 shows comparisons of observed vs. simulated chlorophyll-a variations at the Famosa Channel outlet. Both the predictions and measurements of chlorophyll-a indicate that phytoplankton algal levels are relatively low within the Slough, Channel, and San Diego River, and that phytoplankton algae likely have only a small influence on nutrient and DO levels within these water bodies.

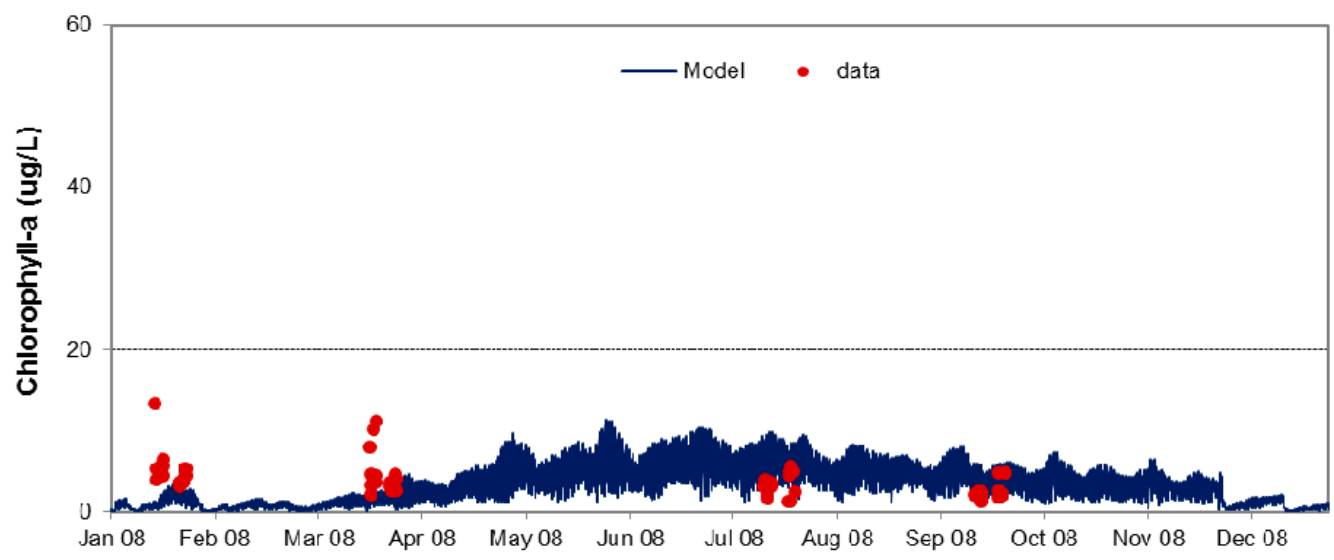

Figure 3. Comparison of observed vs. simulated Chlorophyll-a variations at the outlet of the Famosa Channel. 


\subsubsection{Simulation Results of Macroalgae}

EFDC is capable of simulating primary producers in numerous forms, including three water column (transportable) phytoplankton algal groups and one benthic (stationary) algal group. EFDC can simulate one of the three available phytoplankton group as diatoms, wherein silicon is also included as a limiting nutrient. EFDC can also simulate one of the three available phytoplankton groups as blue-green algae, wherein atmospherically derived dissolved nitrogen gas within the water column may be reduced and used directly as an inorganic nitrogen nutrient source.

During the current calibration the three available phytoplankton groups were reduced to one broad group, with metabolism controlled only by water temperature, light, and water column levels of nitrogen and phosphorus. Monitoring conducted between 2007 and 2008 [34] suggests that benthic and surface algal forms, such as floating macro algal mats (summer), blue-green algal mats (fall), benthic macroalgae deposits, and benthic infaunal species, exist in the Famosa Slough and Famosa Channel during much of the year. In addition, photographs from monitoring indicate that rooted macrophytes (seagrass) are also present but were not quantified. Furthermore, it was concluded that these algal groups dominate DO resources, nutrient cycling, and observed levels of eutrophication within these water bodies. During the current calibration, EFDC was used to simulate these diverse groups of observed fixed surface and benthic algal species as two broad algal groups: floating macroalgae and benthic macroalgae.

Figure 4 presents the simulated macroalgae at the sampled transect against the observed data. Since the transect covers a range a modeled grid cells, the model results at those cells are extracted and the minimum and maximum values were calculated and plotted to represent the range. Figure 4 indicates that the benthic macroalgae grows earlier in the year and dominates the floating macroalgae from March to May. The floating macroalgae biomass starts to grow in April and then outcompetes benthic algae after May through the end of the year. This simulated seasonal variability in benthic and floating macroalgae matches the observed pattern in McLaughlin et al. [34]. One measured value is available at this transect and is compared with the model result. The model predicted macroalgae biomass at this transect matched the measured data very well for the period. The general match in magnitude between the model results and data suggest that the model performs reasonably well in achieving the macroalgae dynamics in the system. On the other hand, it should be noted that one data point is far from sufficient to fully establish the accuracy of the model. To further improve the reliability of the model, it is recommended that macroalgae data be collected at more transects and times in the future, which can then be used to further validate and refine the model.

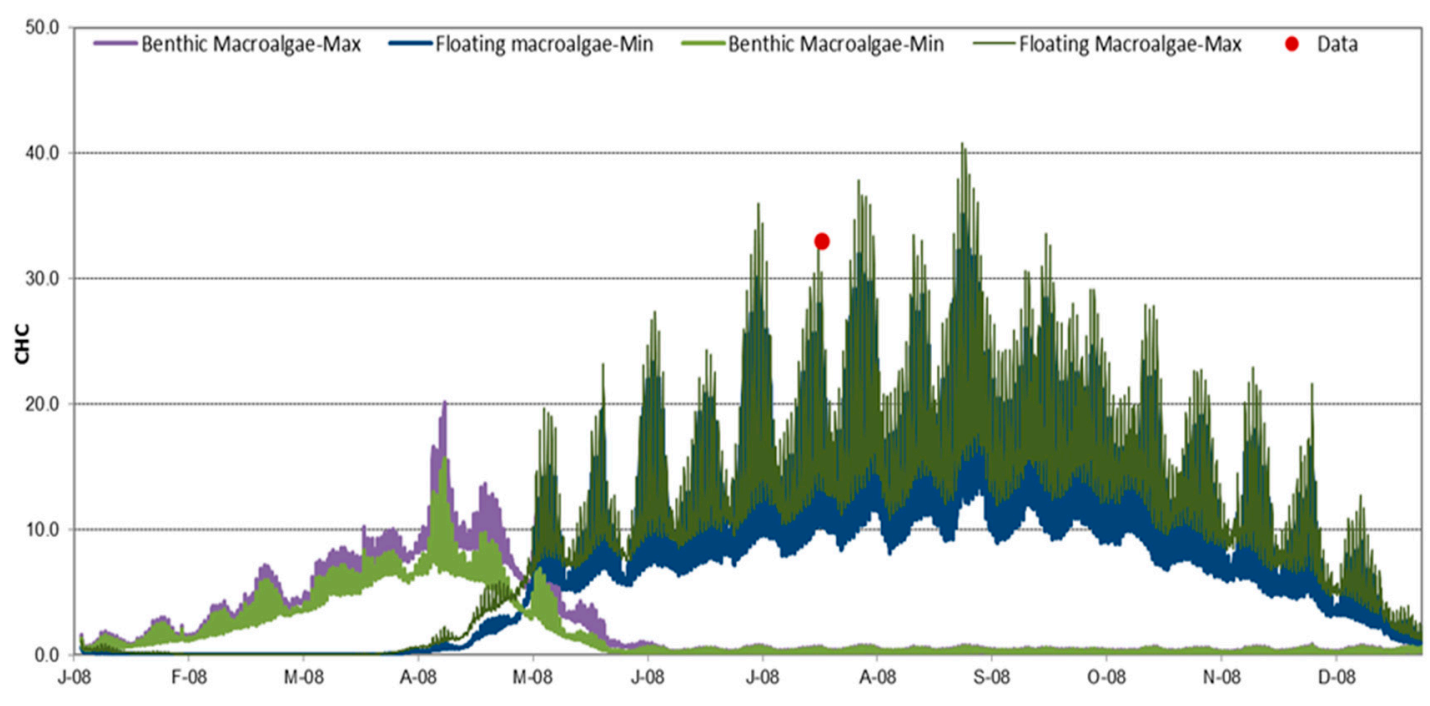

Figure 4. Simulated macroalgae at the monitored transect. 


\subsubsection{Simulation Results of Dissolved Oxygen (DO)}

Both the predictions and measurements of DO suggest that the high levels of macroalgae density and metabolism within the Slough and Channel have a major influence on nutrient and DO variations within these water bodies. Considering significant uncertainty may exist in the DO sonde data, the model calibration focused on reproducing the general trend and magnitude represented by the observed DO data instead of the detailed short-term variations. As shown in Figure 5, the model predicts both the seasonal DO variability well, particularly for the critical summer period of June to August, and the model simulated diurnal DO ranges with the observed data at the SEG and outlet stations with very high accuracy. The performance of the updated model improved significantly at the SEG and outlet stations.

Similar variations in DO levels were observed during July of 2008, within the tidal reach of the San Diego River [35]. Daytime DO levels within the San Diego River estuary were measured in excess of $17 \mathrm{mg} / \mathrm{L}$ and water column chlorophyll-a levels were found to be low $(<6 \mu \mathrm{g} / \mathrm{L})$, suggesting that benthic macroalgae may also have a major impact on DO resources within this adjacent, interconnected waterbody.

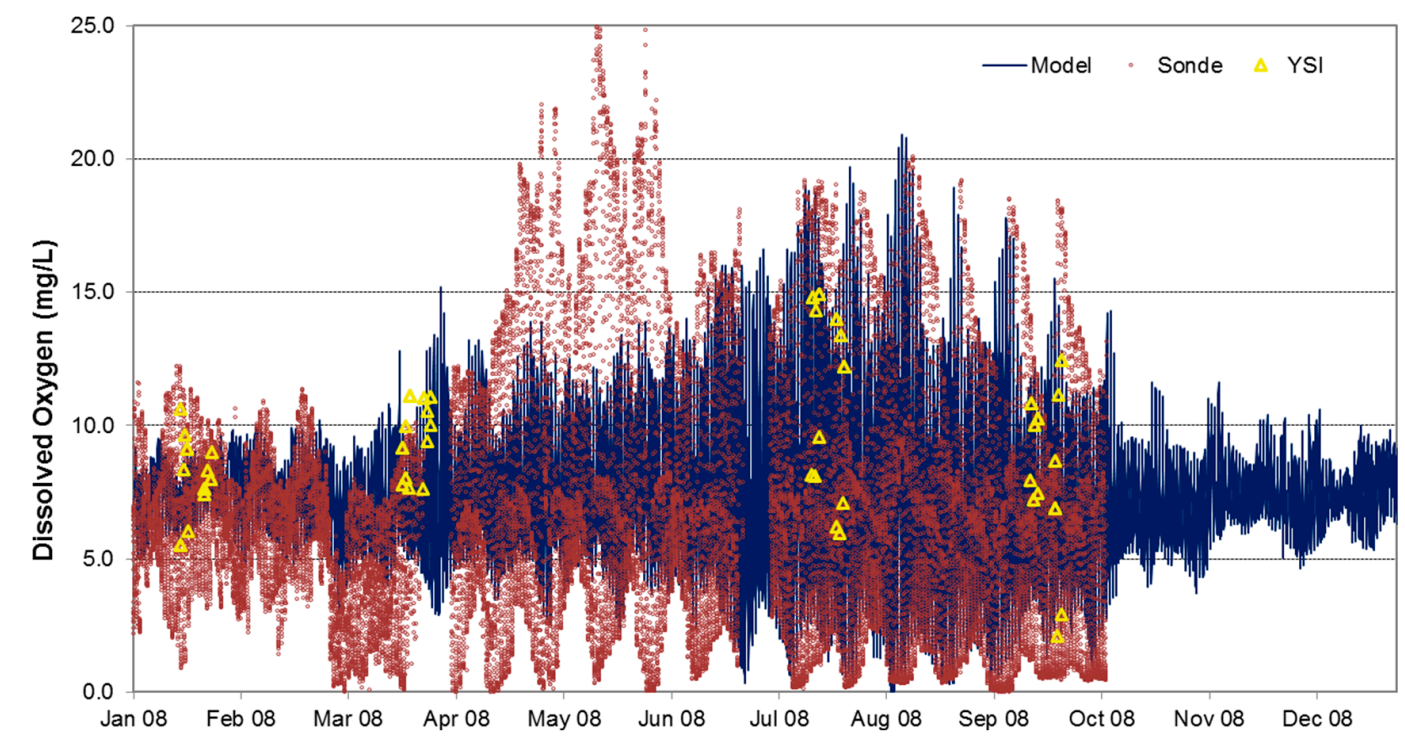

Figure 5. Comparison of observed vs. simulated DO (Dissolved Oxygen) variations at the outlet of the Famosa Channel.

\subsubsection{Simulation Results of Nutrients}

Figure 6 compares EFDC predicted and measured concentrations of phosphorus constituents $\left(\mathrm{PO}_{4}{ }^{3-}-\mathrm{P}\right.$ and TP) and nitrogen constituents $\left(\mathrm{NH}_{4}{ }^{+}-\mathrm{N}, \mathrm{NO}_{3}-\mathrm{N}\right.$, and $\left.\mathrm{TN}\right)$ at the outlet monitoring locations. Large spikes in levels of all the predicted nutrient constituents are seen for the January and February 2008 period, when rainfall/runoff events occurred. All of the constituents at the outlet are represented relatively well by the model. Note that the model simulates the significant diurnal fluctuation that is occurring due to the highly productive nature of the Famosa Slough and the Channel. Benthic macroalgae and floating macroalgae consume significant amounts of nutrients during the day. Since monitoring occurred during the day, when nutrient concentrations are depleted, the data, particularly during the later spring/summer/fall period, are generally low. This is fully represented by the model simulations.

The result does show that the model tends to over-predict phosphorus during the early stage of the year, which might be due to the over prediction of phosphorus from the watershed model. Since the model's overall performance was evaluated by multiple lines of evidences, including nutrient, macroalgae seasonal variability, and magnitude of biomass, and especially with the seasonal and 
diurnal DO pattern, we can have reasonable confidence in the model's capability in representing the nutrient-macroalgae dynamics subjected to the uncertainty due to limited data. In the future, upon the availability of additional data, the model can be further verified and improved.

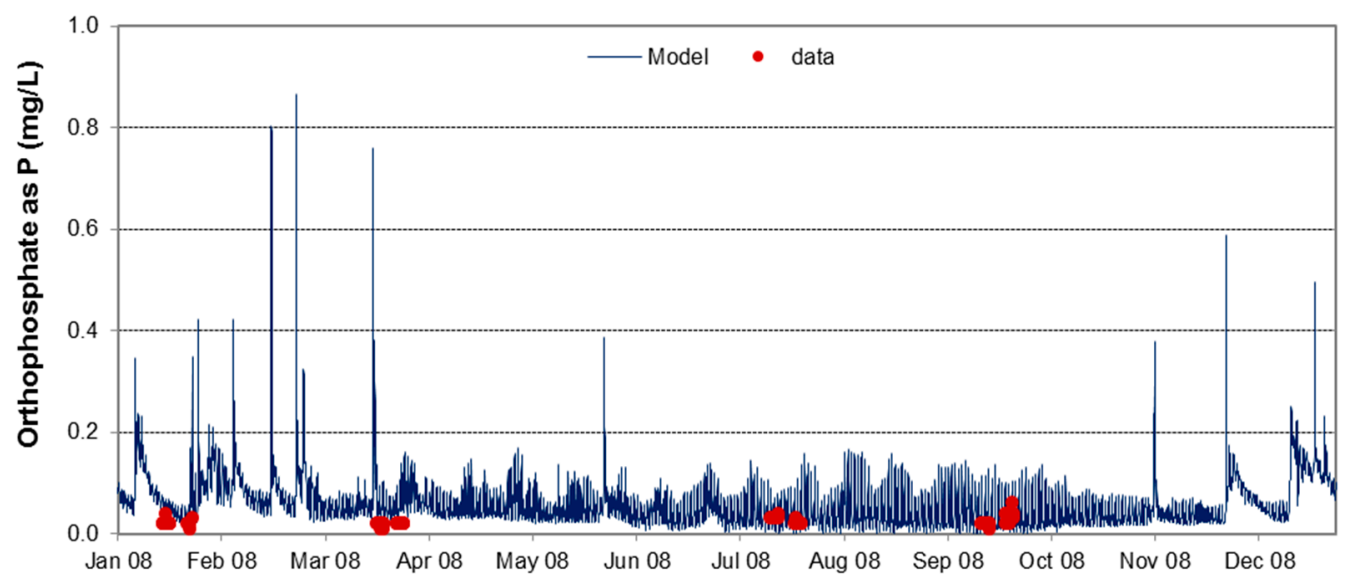

(a)

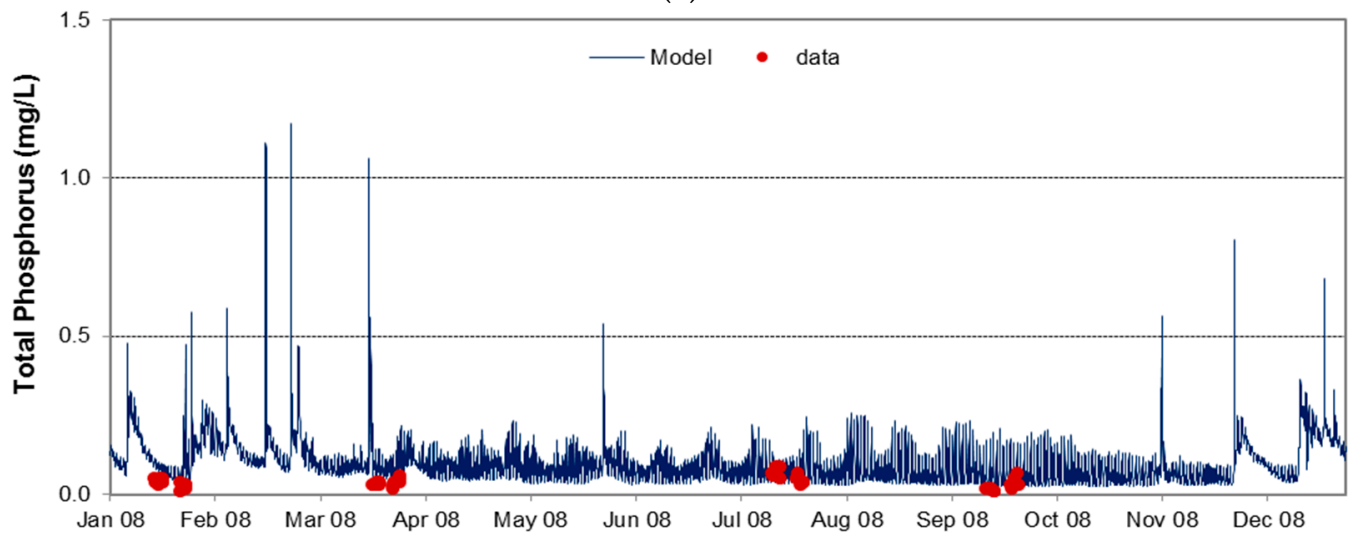

(b)

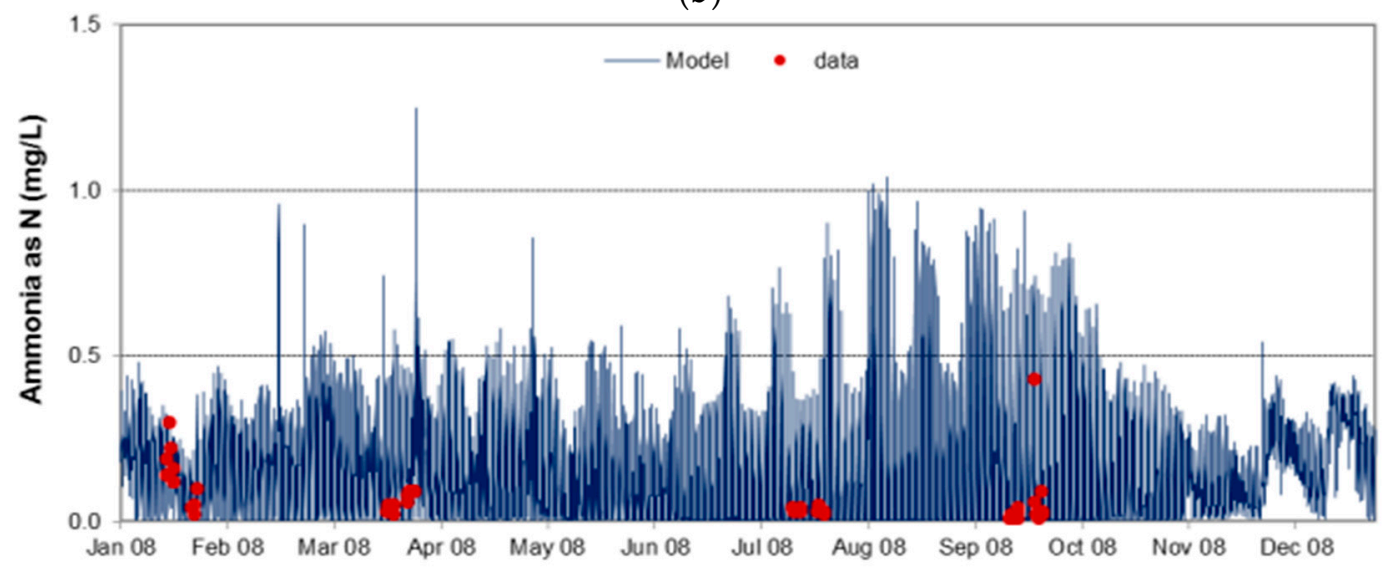

(c)

Figure 6. Cont. 


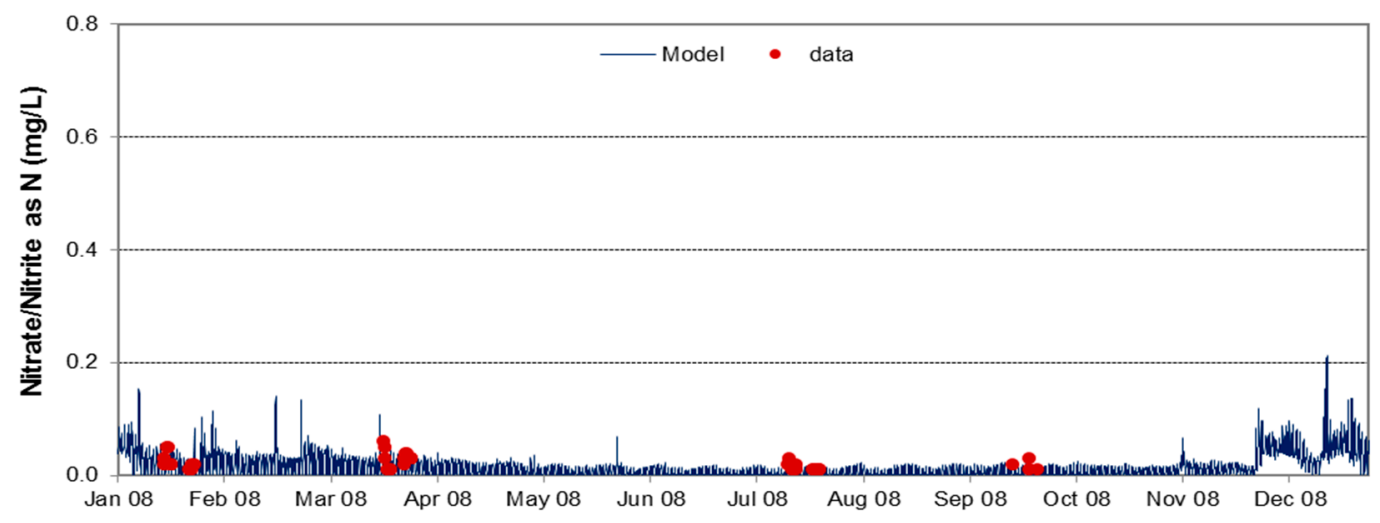

(d)

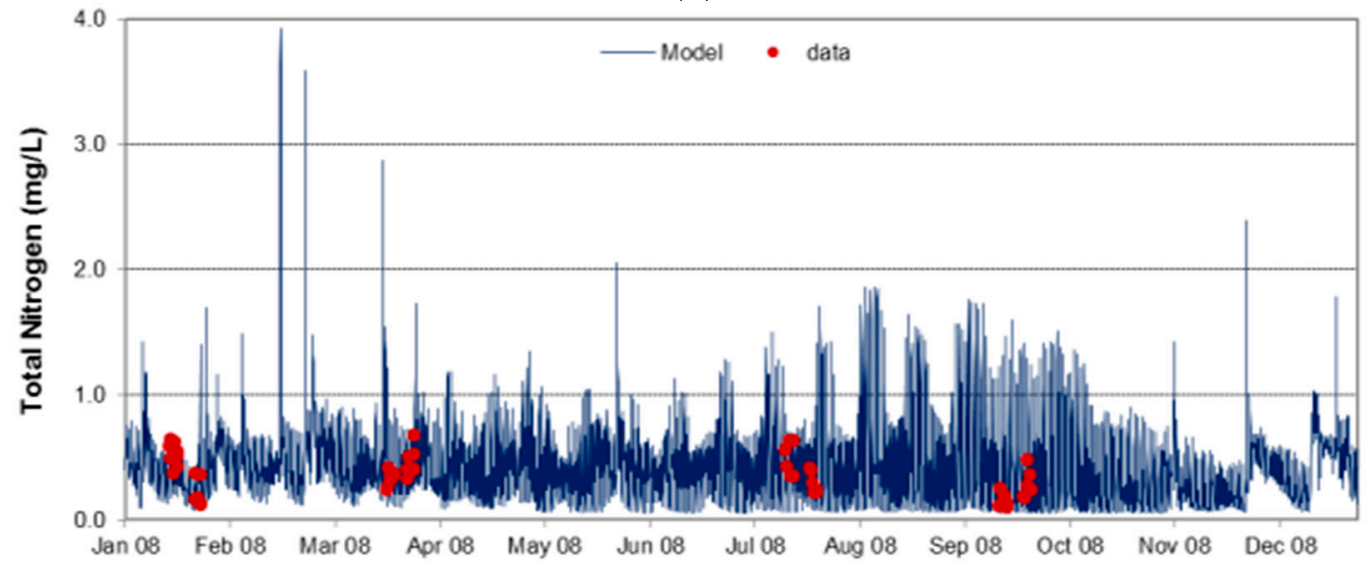

(e)

Figure 6. Comparison of Observed vs. Simulated Variations for $\mathrm{PO}_{4}{ }^{3-}-\mathrm{P}(\mathrm{a}), \mathrm{TP}(\mathbf{b}), \mathrm{NH}_{4}{ }^{+}-\mathrm{N}$ (c), $\mathrm{NO}_{3}{ }^{-}-\mathrm{N}(\mathbf{d})$, and $\mathrm{TN}(\mathbf{e})$ at the Famosa Channel outlet.

\section{Management Scenarios}

The calibrated model was applied to analyze a series of management scenarios to estimate potential water quality benefits. The purpose of these scenarios is to establish a quantitative understanding of the water quality response to various management options, thereby providing the basis for determining cost-effective implementation actions in the future. To produce more scientific support for water quality improvement management, the following scenarios were evaluated. Note that the scenario numbering follows the list of management scenarios that were originally listed for the project. Scenario 3 is not listed above, but represents the iterative simulations that will be necessary to achieve the numeric TMDL targets when developed.

Scenario 1: Baseline condition for the evaluation of all remaining management scenarios. Model setup was based on the calibrated hydrodynamic and water quality model using the existing watershed, San Diego River, and open ocean boundary conditions. The boundary condition was recycled annually to develop a 10-year continuous simulation period. The number of modeled years (10) was determined to be the length of time that would allow the model to reach a near steady-state condition that reflects the response of benthic sediment to changes in watershed loading condition and other factors.

Scenario 2: 95\% reduction in watershed and San Diego River nutrient loads. No change to open ocean boundary conditions.

Scenario 4: $80 \%$ reduction in watershed loads. No change to open ocean boundary conditions and San Diego River loads. 
Scenario 5: 80\% reduction in San Diego River loads. No change to open ocean boundary conditions and watershed loads.

Scenario 6: Once-a-year harvesting of floating macroalgae on the peak date based on the baseline model results. Assumed removal of $90 \%$ of the floating macroalgae biomass instantaneously on the specified date.

Scenario 6b: Once-a-year harvesting of floating macroalgae on the peak date based on the baseline model results. Assumed removal of $95 \%$ of the floating macroalgae biomass instantaneously on the specified date.

Scenario 7: Twice-a-year harvesting of floating macroalgae on 1 July and 1 September. Assumed $95 \%$ of the floating macroalgae biomass instantaneously on the specified date.

Scenario 8: One time dredging throughout Famosa Slough and the Channel, which represents removing $95 \%$ of the sediment bed nutrients at the beginning of the first simulation year. No change to the model bathymetry.

Scenario 9: Reconfiguration of the model based on the recommended water circulation enhancements provided in the PWA (Philip Williams \& Associates) report (i.e., separate east and west channels, and install tidal gate to control flow directions at the culverts).

Scenario 10: Combination of twice-a-year harvesting of floating macroalgae (refer to Scenario 7) and a $60 \%$ reduction in watershed loads. No change to open ocean boundary conditions, San Diego River loads, and other model components.

\section{Results and Discussion}

As shown in Figure 7, when the watershed and San Diego River nutrient loadings were reduced by $95 \%$, floating and benthic macroalgae showed reduced biomass levels. Also, DO concentrations in the Slough no longer showed significant diurnal fluctuation, and the daily minimum DO concentration was significantly improved. Scenario 2 demonstrates significant benefits from substantial reduction of nutrient loading from both the watershed and San Diego River. Scenarios 4 and 5 were designed to explore whether a reduction in watershed loading or San Diego River loading alone can produce a significant response. The results show significant improvement from an $80 \%$ reduction in nutrient loading from the watershed alone. However, an $80 \%$ reduction in loading from the San Diego River only produces marginal improvement in water quality in the Slough, thereby suggesting that managing nutrients from the watershed of the Famosa Slough alone without stretching to the San Diego River poses an effective option for achieving water quality improvements. This finding was important since it help decision makers dismiss the previous consideration of managing nutrient loading from the San Diego River, which is much more expensive than focusing on the Famosa watershed alone.

The conventional TMDL wisdom usually focuses on watershed load reduction alone [21,28,30,33,37]. However, for the Famosa Slough, it was suggested that harvesting floating macroalgae or dredging might also have water quality benefits because the floating algal mats and benthic flux are dominant features in the slough [34]. This study extends the analysis beyond the traditional TMDL load reduction by exploring other management options that might also be effective in improving the water quality in the slough; Scenarios 6 and $6 \mathrm{~b}$ focused on evaluating the response to harvesting floating macroalgae throughout the system. The difference between Scenario 6 and $6 \mathrm{~b}$ is that the former assumes a slightly lower removal (90\% versus $95 \%)$. 

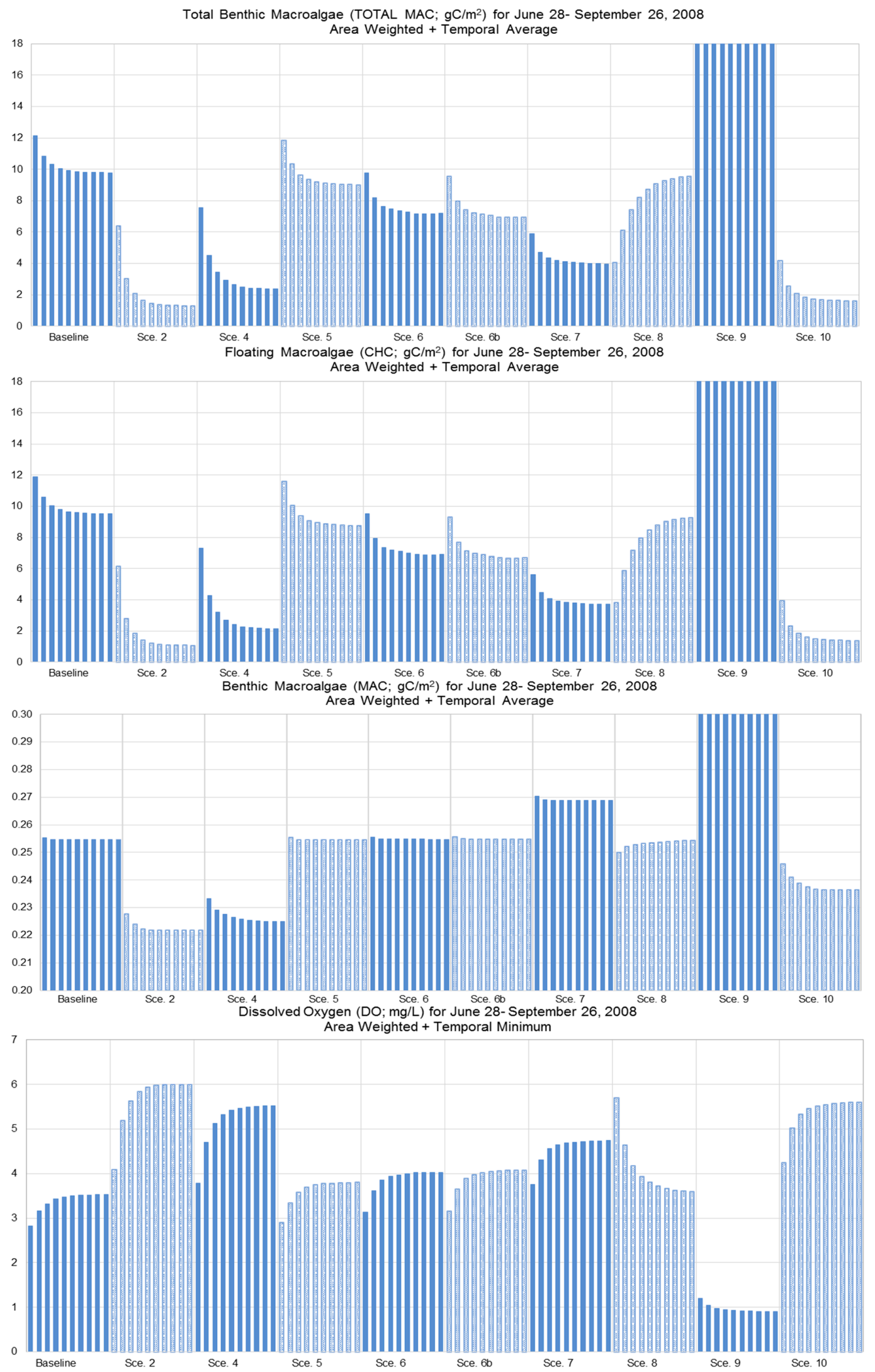

Figure 7. Spatially and temporal average water quality in the Famosa Slough for all Scenarios. 
As shown, these two harvesting scenarios resulted in an overall reduction in biomass for both floating macroalgae and benthic macroalgae, in contrast to the original anticipation that benthic macroalgae may be enhanced due to the removal of floating macroalgae. This is due to the fact that the floating macroalgae harvest was conducted during the late summer time period but benthic macroalgae in Famosa grow primarily during late winter and spring [34]. Although removal of floating macroalgae alleviates the light limiting condition during late summer, it does not benefit the benthic algae because it is beyond its active growth season. However, harvesting reduces the nutrient concentration in the system which may depress the growth of benthic macroalgae during the growth season. Combining these two factors, the light condition improvement may not be sufficient to offset the limitation from reduced nutrients in this case, causing the benthic macroalgae to also decrease. However, care should be taken in the interpretation of these results because of the complex dynamics between algal growth and the competition for light, nutrients, and other factors. In some situations, it would be reasonable to expect that the benthic algae biomass may increase depending on the combination of these factors such as time of year to harvest, water levels, and water temperature. Further insights can be gained later in the analysis of Scenario 7.

Although Scenarios 6 and $6 \mathrm{~b}$ resulted in a noticeable reduction in macroalgae biomass, the response may not be significant enough to improve water quality conditions to an acceptable level. To further explore the algal harvesting alternative, Scenario 7 evaluated the potential benefits of twice-a-year harvesting of floating macroalgae. Under this scenario, floating macroalgae was initially harvested at the beginning of the critical period, then again later when biomass levels became elevated again. As shown in Figure 8, by harvesting floating macroalgae twice-a-year, macroalgae biomass was reduced significantly, suggesting that algal harvesting may be a viable alternative for improving water quality conditions. The figure shows no significant improvement in total nitrogen and phosphorus; this is because the major reduction in nutrients is due to the benthic flux that is in the form of inorganic nutrient components, while the total nutrients contain organic components from the watershed and San Diego River which is not reduced.
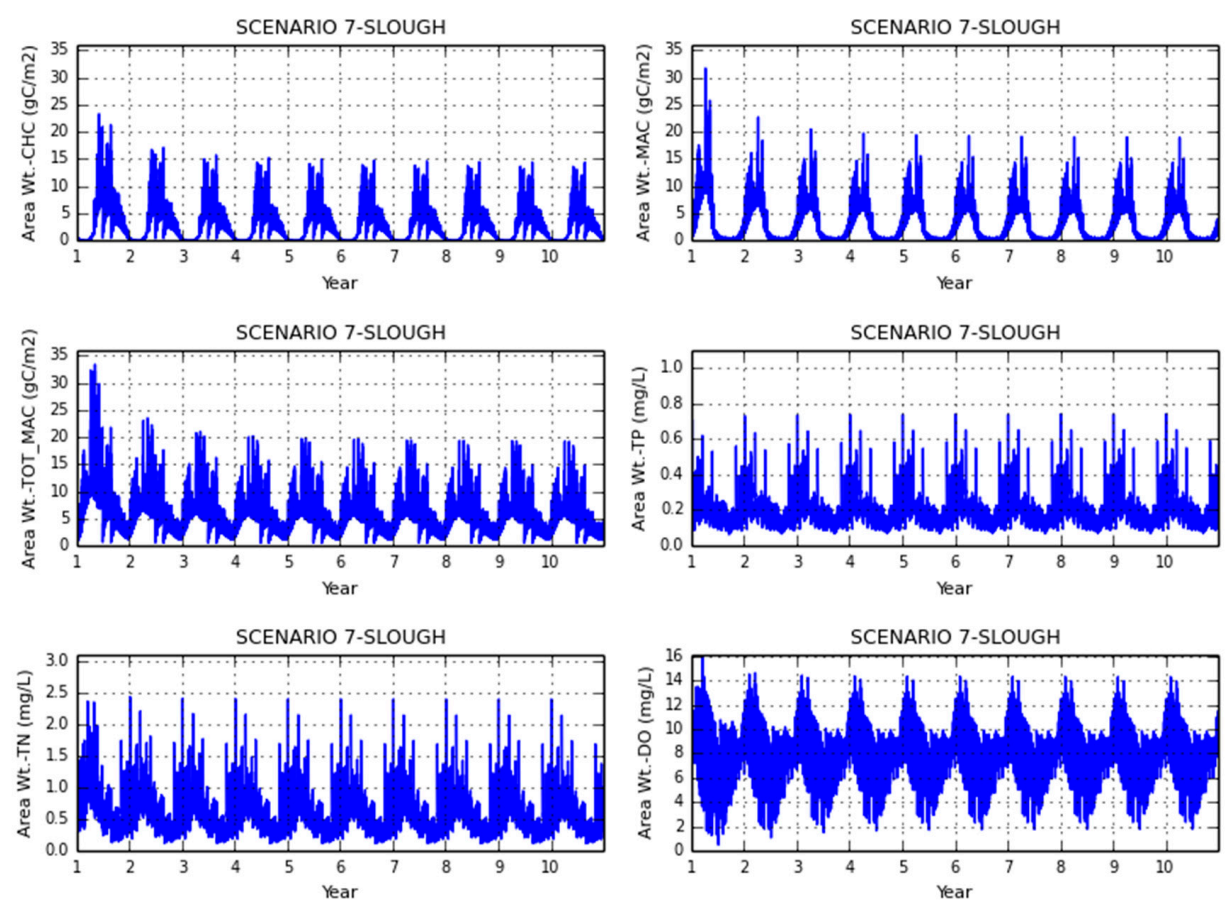

Figure 8. Average water quality in the Famosa Slough under Scenario 7.

It can be seen that under Scenario 7, the benthic macroalgae biomass slightly increased when twice-a-year harvesting is implemented. This is because the first harvest occurs in early summer, 
so harvesting the floating macroalgae at this time results in better light conditions for benthic macroalgae. The early summer is still within the active growth season for the local benthic algae groups, thus the better light condition was able to result in slightly enhanced growth. Since in the Famosa Slough, the growth of benthic algae/macrophyte is considered more a beneficial phenomenon than an impairment, the slight enhancement of benthic algae in the early summer is also considered a desired outcome. The seasonal average daily minimum DO results also show significant benefit when watershed loading is tremendously reduced. In addition, the negative impact of the circulation scenario on macroalgae and daily minimum DO is also shown in Figure 7.

Another management option considered in this study was to dredge the nutrient enriched bed sediment to remove this significant internal source. Scenario 8 was designed to analyze this option, which essentially represents the removal of $95 \%$ of the sediment nutrient concentrations at the beginning of the 10-year simulation. This provides a clean bed sediment initial condition for the sediment diagenesis model, which then changes over time based on external load contributions. It is interesting to note that after the dredging, macroalgae and DO concentrations both significantly improved in the Slough initially, which is consistent with the conclusions from previous studies that suggest benthic flux and SOD are significant contributors to the water quality problems in the Famosa Slough. However, the model results also demonstrate that these benefits degrade rapidly over time and become insignificant after several years. Therefore, while dredging can be an effective water quality restoration option, decision makers should keep in mind that the effectiveness might only last for a short period if watershed loading remains unchanged. Considering that dredging is expensive, its applications should be cautiously evaluated using modeling techniques before implementation. We believe that water quality restoration efforts in other systems might also benefit from a more refined design procedure relying on numerical modeling to evaluate whether dredging can potentially benefit the system under concern and whether the effectiveness would last long enough to justify the high cost.

In addition to load reduction, macroalgae harvesting, and dredging, one option previously considered was to modify the circulation pattern in the Slough. A previous study conducted by PWA used a 1-dimensional hydrodynamic model to evaluate the effects of several enhancements to water circulation in the Slough [39]. The study recommended installing a tidal gate and barriers to convert the two-way circulation through the culverts to a one-way circulation that would improve flushing, and was hypothesized to have potential water quality benefits. While the study was reasonably designed conceptually, the modeling approach was not anticipated to produce reliable results because it represented the Famosa Slough as a 1-dimensional hydrodynamic model, without representing the spreading of water throughout the shallow marsh area. In addition, the model was a pure hydrodynamic model without representation of the complex water quality dynamics. These enhancements were modeled in this study (Scenario 9) using the full 2-dimensional hydrodynamic and water quality model. The model shows degraded water quality conditions as a result of these enhancements in terms of macroalgae biomass and DO. This result contradicts the previous recommendations mainly because the previous model oversimplifies the Famosa Slough into a 1-dimensional channel; therefore, the representation of the hydrodynamics is inaccurate. The current model reflects the wetting-and-drying caused by tidal impacts and freshwater inflows, and allows the water to spread and withdraw from the shallow tidal marsh area, which is more realistic and representative. In this more realistic setting, the installation of a tide gate prevents water flushing from the west side culverts. This essentially slows down the exchange of water between the Slough and the Channel, retaining nutrient loading in the slough longer which further worsens the macroalgae and DO impairment. This analysis suggests that in applying numerical models for decision support, the models must be developed such that it is representative to the physical characteristics of the system. In this case, the Famosa Slough system is apparently a tidal marsh area characterized by a 2-dimensional domain feature, and the previous modeling effort over-simplified the system into a 1-dimensional representation, hence is not able to reproduce the realistic conditions for accurate prediction. 
Based on the results of the previous scenarios, an additional scenario (Scenario 10) was evaluated, which included the combined effects from watershed load reduction and algal harvesting. The purpose of this scenario was to explore whether combined watershed management and harvesting can provide a more cost-effective option for restoring water quality in the Slough. In this scenario, a less extreme watershed load reduction $(60 \%)$ was introduced together with a twice-a-year harvesting schedule. The results show significant water quality benefits, suggesting that it may be worthwhile to further explore combined management options for implementation.

An important note is that watershed management must be implemented in an adaptive management manner, through which continuous data collection and model refinement will be needed. As discussed earlier, even though the model was reasonably calibrated and the overall behavior of the model demonstrated in the scenario analysis also makes sense, there is no guarantee that the model has represented all the key processes in the system. Therefore, the above model results should be interpreted with the model uncertainty kept in mind, and the model should be updated whenever more data are available to improve its reliability. In other words, the model should be regarded as an evolving decision support tool rather than a once-for-all static analysis platform.

\section{Conclusions}

This study has developed an integrated hydrodynamic and water quality model for the Famosa Slough through enhancing a previous version of the model based on EFDC. The major enhancements include improving the macroalgae representation through explicitly simulating floating and benthic macroalgae groups separately based on their characteristics, and improving the predictive capability through adding a sediment diagenesis model to directly simulate the interaction between watershed loading, ocean boundary loading, San Diego River loading, and benthic nutrient flux and SOD. The enhanced model was applied to analyze multiple management scenarios focusing on different aspects of controlling processes: watershed load reduction, macroalgae harvesting, dredging, and the combination of different options. Overall, the modeling analysis resulted in the following conclusions:

(1) It is advantageous to apply an integrated water quality model to evaluate water quality restoration options before blindly implementing options that might not be cost-effective, as shown in the scenario analysis results.

(2) Reduction of nutrient load contributions can produce significant water quality benefits, however, not all the source reductions are effective. The analysis finds that reduction of nutrient load from the San Diego River, which was previously considered an option by local decision makers, is not a cost-effective solution and thus should be abandoned.

(3) It is important to explore options from multiple aspects in the decision making process for water quality restoration. This study finds that in addition to the conventional wisdom of watershed load reduction, harvesting floating macroalgae can also have significant water quality benefits. Actually, a combination of moderate watershed load reductions coupled with periodic macroalgae harvesting provided significant water quality benefits and represents a more cost-effective approach than load reduction alone.

(4) Dredging can generate immediate water quality benefits; however, the benefits degraded rapidly without corresponding reductions in external loading. Thus it is not recommended as a desired option for Famosa water quality restoration.

(5) The circulation modification option is unlikely to produce the anticipated benefit inferred from a previous 1-dimensional hydrodynamic model. This suggests that to more reliably predict the water quality response to management options, it is important to use models which more closely represent the physical characteristics of the system.

(6) With the current available data, the model developed in this study might still be subjected to significant uncertainty. Modeling is an evolving process and should be embedded in the adaptive management process to continuously provide more reliable analysis with the availability of new data. 


\section{References}

1. Camargo, J.A.; Alonso, Á. Ecological and toxicological effects of inorganic nitrogen pollution in aquatic ecosystems: A global assessment. Environ. Int. 2006, 32, 831-849. [CrossRef] [PubMed]

2. Hooda, P.; Edwards, A.; Anderson, H.; Miller, A. A review of water quality concerns in livestock farming areas. Sci. Total Environ. 2000, 250, 143-167. [CrossRef]

3. Schoumans, O.; Chardon, W.; Bechmann, M.; Gascuel-Odoux, C.; Hofman, G.; Kronvang, B.; Rubæk, G.H.; Ulén, B.; Dorioz, J.-M. Mitigation options to reduce phosphorus losses from the agricultural sector and improve surface water quality: A review. Sci. Total Environ. 2014, 468, 1255-1266. [CrossRef] [PubMed]

4. Xiong, J.; Wang, X.C.; Zhang, Q.; Duan, R.; Wang, N. Characteristics of a landscape water with high salinity in a coastal city of China and measures for eutrophication control. Ecol. Indic. 2016, 61, 268-273. [CrossRef]

5. Meyer-Reil, L.-A.; Köster, M. Eutrophication of marine waters: Effects on benthic microbial communities. Mar. Pollut. Bull. 2000, 41, 255-263. [CrossRef]

6. Zamparas, M.; Zacharias, I. Restoration of eutrophic freshwater by managing internal nutrient loads. A review. Sci. Total Environ. 2014, 496, 551-562. [CrossRef] [PubMed]

7. Smith, V.H. Eutrophication of freshwater and coastal marine ecosystems a global problem. Environ. Sci. Pollut. Res. 2003, 10, 126-139. [CrossRef]

8. Dodds, W.K.; Bouska, W.W.; Eitzmann, J.L.; Pilger, T.J.; Pitts, K.L.; Riley, A.J.; Schloesser, J.T.; Thornbrugh, D.J. Eutrophication of US freshwaters: Analysis of potential economic damages. Environ. Sci. Technol. 2008, 43, 12-19. [CrossRef]

9. Hoffmann, C.C.; Kjaergaard, C.; Uusi-Kämppä, J.; Hansen, H.C.B.; Kronvang, B. Phosphorus retention in riparian buffers: Review of their efficiency. J. Environ. Qual. 2009, 38, 1942-1955. [CrossRef] [PubMed]

10. Duarte, C.M.; Conley, D.J.; Carstensen, J.; Sánchez-Camacho, M. Return to Neverland: Shifting baselines affect eutrophication restoration targets. Estuaries Coasts 2009, 32, 29-36. [CrossRef]

11. Qiu, D.; Wu, Z.; Liu, B.; Deng, J.; Fu, G.; He, F. The restoration of aquatic macrophytes for improving water quality in a hypertrophic shallow lake in Hubei Province, China. Ecol. Eng. 2001, 18, 147-156. [CrossRef]

12. Palmer, M.A.; Filoso, S.; Fanelli, R.M. From ecosystems to ecosystem services: Stream restoration as ecological engineering. Ecol. Eng. 2014, 65, 62-70. [CrossRef]

13. Le, C.; Zha, Y.; Li, Y.; Sun, D.; Lu, H.; Yin, B. Eutrophication of lake waters in China: Cost, causes, and control. Environ. Manag. 2010, 45, 662-668. [CrossRef] [PubMed]

14. Jeppesen, E.; Søndergaard, M.; Meerhoff, M.; Lauridsen, T.L.; Jensen, J.P. Shallow lake restoration by nutrient loading reduction—some recent findings and challenges ahead. Hydrobiologia 2007, 584, 239-252. [CrossRef]

15. Chen, K.-N.; Bao, C.-H.; Zhou, W.-P. Ecological restoration in eutrophic Lake Wuli: A large enclosure experiment. Ecol. Eng. 2009, 35, 1646-1655. [CrossRef]

16. Zou, R.; Bai, S.; Parker, A. Hydrodynamic and eutrophication modeling for a tidal marsh impacted estuarine system using EFDC. In Estuarine and Coastal Modeling (2007); American Society of Civil Engineers: Reston, VA, USA, 2008; pp. 561-589.

17. Wan, Y.; Ji, Z.-G.; Shen, J.; Hu, G.; Sun, D. Three dimensional water quality modeling of a shallow subtropical estuary. Mar. Environ. Res. 2012, 82, 76-86. [CrossRef] [PubMed]

18. Liu, X.; Huang, W. Modeling sediment resuspension and transport induced by storm wind in Apalachicola Bay, USA. Environ. Model. Softw. 2009, 24, 1302-1313. [CrossRef]

19. Jeong, S.; Yeon, K.; Hur, Y.; Oh, K. Salinity intrusion characteristics analysis using EFDC model in the downstream of Geum River. J. Environ. Sci. 2010, 22, 934-939. [CrossRef]

20. Zhou, J.; Falconer, R.A.; Lin, B. Refinements to the EFDC model for predicting the hydro-environmental impacts of a barrage across the Severn Estuary. Renew. Energy 2014, 62, 490-505. [CrossRef]

21. Zou, R.; Carter, S.; Shoemaker, L.; Parker, A.; Henry, T. Integrated hydrodynamic and water quality modeling system to support nutrient total maximum daily load development for Wissahickon Creek, Pennsylvania. J. Environ. Eng. 2006, 132, 555-566. [CrossRef]

22. Wu, G.; Xu, Z. Prediction of algal blooming using EFDC model: Case study in the Daoxiang Lake. Ecol. Model. 2011, 222, 1245-1252. [CrossRef]

23. Hamrick, J.M.; Mills, W.B. Analysis of water temperatures in Conowingo Pond as influenced by the Peach Bottom atomic power plant thermal discharge. Environ. Sci. Policy 2000, 3, 197-209. [CrossRef] 
24. Warner, J.C.; Sherwood, C.R.; Signell, R.P.; Harris, C.K.; Arango, H.G. Development of a three-dimensional, regional, coupled wave, current, and sediment-transport model. Comput. Geosci. 2008, 34, 1284-1306. [CrossRef]

25. Seo, D.; Sigdel, R.; Kwon, K.; Lee, Y. 3-D hydrodynamic modeling of Yongdam Lake, Korea using EFDC. Desalination Water Treat. 2010, 19, 42-48. [CrossRef]

26. Zhao, X.; Shen, Z.; Xiong, M.; Qi, J. Key uncertainty sources analysis of water quality model using the first order error method. Int. J. Environ. Sci. Technol. 2011, 8, 137-148. [CrossRef]

27. Liu, Z.; Hashim, N.B.; Kingery, W.L.; Huddleston, D.H.; Xia, M. Hydrodynamic modeling of St. Louis Bay estuary and watershed using EFDC and HSPF. J. Coast. Res. 2008, 107-116. [CrossRef]

28. Zhao, L.; Li, Y.; Zou, R.; He, B.; Zhu, X.; Liu, Y.; Wang, J.; Zhu, Y. A three-dimensional water quality modeling approach for exploring the eutrophication responses to load reduction scenarios in Lake Yilong (China). Environ. Pollut. 2013, 177, 13-21. [CrossRef] [PubMed]

29. Gong, R.; Xu, L.; Wang, D.; Li, H.; Xu, J. Water Quality Modeling for a Typical Urban Lake Based on the EFDC Model. Environ. Model. Assess. 2016, 21, 643-655. [CrossRef]

30. Liu, Y.; Wang, Y.; Sheng, H.; Dong, F.; Zou, R.; Zhao, L.; Guo, H.; Zhu, X.; He, B. Quantitative evaluation of lake eutrophication responses under alternative water diversion scenarios: A water quality modeling based statistical analysis approach. Sci. Total Environ. 2014, 468, 219-227. [CrossRef] [PubMed]

31. Pak, G.; Mallari, K.J.B.; Baek, J.; Kim, D.; Kim, H.; Jung, M.; Kim, Y.; Yoon, J. Modelling of suspended sediment in a weir reach using EFDC model. Water Sci. Technol. 2016, 73, 1583-1590. [CrossRef] [PubMed]

32. Chen, X.; Shen, Z.; Yang, Y. Response of the turbidity maximum zone in the Yangtze River Estuary due to human activities during the dry season. Environ. Sci. Pollut. Res. 2016, 23, 18466-18481. [CrossRef] [PubMed]

33. Bai, S.; Lung, W.-S. Modeling sediment impact on the transport of fecal bacteria. Water Res. 2005, 39, 5232-5240. [CrossRef] [PubMed]

34. McLaughlin, K.; Sutula, M.; Cable, J.; Fong, P. Eutrophication and Nutrient Cycling in Famsa Slough: A Summary of Baseline Studies for Monitoring order R9-2006-0076; Technical Report 629; Southern California Coastal Water Research Project: Costa Mesa, CA, USA, 2010.

35. Schiff, K.; Gossett, R.; Ritter, K.; Tiefenthaler, L.; Dodder, N.; Lao, W.; Maruya, K. Southern California Bight 2008 Regional Monitoring Program: III. Sediment Chemistry; Southern California Coastal Water Research Project: Costa Mesa, CA, USA, 2011.

36. Thomas, C.; Scott, W. CE-QUAL-W2: A Two-Dimensional, Laterally Averaged, Hydrodynamic and Water Quality Model, Version 3.7 User Manual, 2011. Available online: http:/ /www.cee.pdx.edu/w2/download. html (accessed on 14 April 2017).

37. Zhang, X.; Zou, R.; Wang, Y.; Liu, Y.; Zhao, L.; Zhu, X.; Guo, H. Is water age a reliable indicator for evaluating water quality effectiveness of water diversion projects in eutrophic lakes? J. Hydrol. 2016, 542, 281-291. [CrossRef]

38. Philip Williams and Associates, Ltd. Famosa Slough Enhancement Analysis; Technical Memorandum, Project 1978; Weston Solutions, Inc.: West Chester, PA, USA, 2009.

39. Tetra Tech, Inc. The Environmental Fluid Dynamics Code Theory and Computation Volume 3: Water Quality Module, 2007. Available online: https:/ /www.epa.gov/exposure-assessment-models/efdc-manuals (accessed on 14 April 2017).

(C) 2017 by the authors. Licensee MDPI, Basel, Switzerland. This article is an open access article distributed under the terms and conditions of the Creative Commons Attribution (CC BY) license (http:/ / creativecommons.org/licenses/by/4.0/). 